\title{
PENGARUH KEPEMIMPINAN TRANSAKSIONAL KEPALA SEKOLAH DAN MOTIVASI KERJA GURU TERHADAP KINERJA GURU DI SMP NEGERISE-KECAMATAN RASAU JAYA
}

\author{
Andhika, Aswandi, M. Chiar \\ Program Studi Magister Adminitrasi Pendidikan FKIP Untan Pontianak \\ Email: menteng.undip.proter@gmail.com
}

\begin{abstract}
This study aims to determine how the performance of teachers, principal transactional leadership, and teacher work motivation, and how the influence of each and all variables simultaneously. The general objective of this study was to determine the effect of transactional leadership and teacher work motivation on teacher performance at SMP Negeri Se, District of Rasau Kubu Raya, Indonesia. This study uses quantitative research methods and uses a questionnaire as a data collection tool. The subjects of this study were 83 junior high school teachers in the district of Rasau Jaya Kubu Raya. The characteristics are a permanent teacher, a minimum of two years of service, civil servant status or not, and a bachelor's degree. The results of the study are: (1) the description of the teacher's performance is high (35.84\%) and the score variation is 174-188; (2) the description of transactional leadership is quite good (39.23\%) and the score variation is 238 - 256; (3) the teacher's work motivation is classified as good (30.19\%) and the variation score is 105-116; (4) transactional leadership has an effect on teacher performance; (5) school climate has an effect on teacher achievement motivation; and (5) simultaneously transactional leadership and teacher work motivation affect teacher performance. The conclusion of this study is that the performance of teachers at SMP Negeri Se District of Rasau Jaya Kubu Raya is influenced by the principal's transactional leadership and teacher work motivation of $43.90 \%$.
\end{abstract}

\section{Keywords: Teaceher Performance, Transactional Leadership, Tecaher Work Motivation}

\section{PENDAHULUAN}

Guru memiliki peran sentral dalam pendidikan, sehingga keberadaan guru sangat menentukan ketercapaian tujuan pendidikan. Guru yang memiliki semangat kerja dan dedikasi tinggi tentu akan berakibat positif terhadap proses pendidikan. Semangat kerja guru menjadi hal yang sangat penting untuk diperhatikan karena akan menentukan kinerja guru tersebut.

Kinerja guru nerupakan suatu hal yang sangat penting. Hal ini dinyatakan oleh Muchal dalam Omari dan Okasheh (2017, p.44) yang mengatakan bahwa "...performance is important for individuals, as achieving tasks can be a source of satisfaction". Berdasarkan pendapat tersebut, diketahui bahwa kinerja guru yang tinggi ini akan banyak memberikan kepuasan bagi guru dan tentu akan berpengaruh terhadap peserta didik.

Istilah kinerja merupakan terjemahan dari bahasa inggris, work performance atau job performance, tetapi dalam bahasa inggrisnya sering disingkat dengan performance saja. Dalam bahasa Indonesia disebut juga dengan prestasi kerja. Kinerja merupakan kegiatan yang dijalankan oleh tiap-tiap individu dalam kaitannya untuk mencapai tujuan yang sudah direncanakan. Berkaitan dengan hal tersebut terdapat beberapa definisi mengenai kinerja. James B. Whitaker dalam Yunus dan Titien (2013, p.110) mengemukakan bahwa kinerja merupakan suatu alat manajemen yang digunakan untuk meningkatkan kualitas pengambilan keputusan dan akuntabilitas.

Pidarta (2004) dalam Manik dan Bustomi (2011, p.100) mengemukakan ada beberapa faktor yang dapat mempengaruhi kinerja guru 
dalam melaksanakan tugasnya yaitu kepemimpinan kepala sekolah, fasilitas kerja, harapan-harapan, dan kepercayaan personalia sekolah. Guterres dan Supartha (2016, p.431), mengatakan bahwa faktor yang dapat mempengaruhi kinerja guru dalam sebuah organisasi diantaranya adalah kepemimpinan yang diberlakukan dalam organisasi tersebut dan motivasi kerja.

Menurut Henry Simamora dalam Mangkunegara (2019, p.14), menjelaskan terdapat tiga faktor yang berpengaruh terhadap kinerja, yaitu: (1) faktor individu (kemampuan, ketrampilan, latar belakang keluarga, tingkat sosial dan demografi seseorang); (2) faktor psikologis (persepsi, peran, sikap, kepribadian, motivasi dan pembelajaran); dan (3) faktor organisasi (sumber daya, desain pekerjaan, kepemimpinan, sistem penghargaan atau reward system dan struktur)".

Berdasarkan pendapat tersebut, kinerja juga dapat dipengaruhi oleh kepemimpinan sebagai unsur dari organisasi di sekolah, dalam hal ini kepemimpinan kepala sekolah. Terdapat beberapa jenis model kepemimpinan, di antaranya kepemimpinan transaksional. Fisher et al., (2005) dalam Algahtany dan Bardai (2019,p.63) mengatakan bahwa, "Transactional leadership is outcome-and task-oriented leadership style that focuses on performance evaluation, rewards, and organization". Kepemimpinan transaksional digambarkan sebagai kepemimpinan yang memberikan penjelasan tentang apa yang menjadi tanggung jawab atau tugas bawahan serta imbalan yang dapat mereka harapkan jika standar yang ditentukan tercapai. Kepemimpinan ini terbuka dalam hal memberikan informasi dan tanggung jawab kepada bawahan. Menurut Robbins and Judge (2013, p.417) pemimpin transaksional mengindentifikasi keinginan atau pilihan bawahan dan membantu mereka mencapai kinerja yang menghasilkan reward yang dapat memuaskan bawahan. Pendapat Gibson (1985, p.35) bahwa faktor lain yang dapat mempengaruhi kinerja guru adalah motivasi dari unsur psikologis individu guru. Keberadaan motivasi secara umum di dalam diri seseorang sangatlah diperlukan.
Menurutnya motivasi sebagai mediator antara kebutuhan dan tingkah laku manusia yang berupa kinerja, tujuan, ataupun prestasi kerja yang dicapai. Sehingga motivasi seseorang memiliki pengaruh terhadap kinerja dan pencapaian prestasinya.

Senada hal tersebut, Robbins \& Judge (2011, p.281) kinerja seseorang sangat dipengaruhi oleh faktor kemampuan (ability), motivasi (motivation), dan kesempatan (opportunity), yaitu performance artinya kinerja merupakan fungsi dari kemampuan, motivasi dan kesempatan.

Motivasi menjadi satu di antara beberapa faktor yang dapat mempengaruhi kinerja. Menurut Uno (2014, p.73), Motivasi kerja guru terdiri dari dua dimensi yaitu motivasi internal dan eksternal. Dimensi internal terdiri dari: tanggung jawab guru dalam melaksanakan tugas, melaksanakan tugas dengan target yang jelas, memiliki tujuan yang jelas dan menantang, ada umpan balik atas hasil pekerjaannya, memiliki perasaan senang dalam bekerja, selalu berusaha untuk mengungguli orang lain serta diutamakan prestasi dari apa yang dikerjajannya. Sementara dimensi eksternal terdiri dari: selalu berusaha untuk memenuhi kebutuhan hidup dan kebutuhan kerjanya, senang memperoleh pujian dari apa yang dikerjakanya, bekerja dengan harapan ingin memperoleh insentif dan bekerja dengan harapan ingin memperoleh perhatian dari teman dan atasan.

Berdasarkan uraian tersebut, tentang pentingnya kinerja guru dikaitkan dengan fakta rendahnya hasil penilaian kinerja guru Kalimantan Barat yang menempati posisi terendah kelima tahun 2015/2016 menjadi dasar peneliti untuk melakukan penelitian tentang "Pengaruh Kepemimpinan Transaksional Kepala Sekolah dan Motivasi Kerja Guru Terhadap Kinerja Guru di SMP Negeri se-Kecamatan Rasau Jaya, Kabupaten Kubu Raya".

Tujuan penelitian ini untuk mengetahui bagaimana gambaran kepemimpinan transaksional Kepala Sekolah terhadap kinerja guru, Pengaruh motivasi kerja terhadap kinerja guru dan Pengaruh kepemimpinan transaksional Kepala Sekolah dan motivasi 
kerja guru terhadap kinerja guru khususnya di SMP Negeri Se Kecamatan Rasau Jaya. Penelitian ini dinilai sangat penting dilakukan untuk memberikan sumbangsih terhadap pengembangan pendidikan khusus di Kota Pontianak dan secara khusus diharapkan dapat memperkaya khazanah keilmuan administrasi pendidikan.

\section{METODE PENELITIAN}

Penelitian ini menggunakan pendekatan yang bersifat kuantitatif dengan teknik korelasi, yaitu dengan menggunakan 2 variabel bebas dan 1 variabel.

Subjek penelitian ini adalah semua guru sekolah khusus jenjang sekolah menengah pertama (SMP) di Kabupaten Kubu Raya khususnya Kecmatan Rasau Jaya yang berjumlah 53 orang dengan karakteristik sebagai guru tetap sekolah atau yayasan, masa kerja minimal dua tahun, status guru PNS dan non-PNS, dan lulusan strata satu (S1). Berdasarkan karakteristik tersebut, maka semua populasi dalam penelitian ini menjadi sampel.

Teknik pengumpulan data secara tidak langsung, yakni menggunakan instrumen berupa kuesioner atau angket berskala likert. Angket diujicobakan terlebih dahulu, kemudian diolah serta dilakukan uji validitas dan reliabilitas menggunakan SPSS versi 19 for Windows.

Uji persyaratan data menggunakan uji validitas, uji reliabilitas, uji normalitas, dan uji linieritas. Kemudian dilakukan uji hipotesis menggunakan uji t, uji F, dan uji regresi ganda.

\section{HASIL PENELITIAN DAN PEMBAHASAN \\ Hasil}

Berdasarkan tabel tersebut (tabel 1) dapat dikatakan bahwa gambaran kepemimpinan transasional kepala sekolah tergolong sering karena dari 53 responden terdapat sebanyak 21 responden atau sebesar 3,9,62\% dengan variasi jumlah skor dari 238-256
Tabel 1. Distribusi Frekuensi Variable Kepemimpinan Transaksional Kepala Sekolah

\begin{tabular}{|c|c|c|c|c|}
\hline $\begin{array}{c}\text { No } \\
\text { Kelas }\end{array}$ & Interval & $\begin{array}{c}\text { Frekuensi } \\
\text { Absolut }\end{array}$ & $\begin{array}{c}\text { Frekuensi } \\
\text { Relatif } \\
(\%)\end{array}$ & Kategori \\
\hline 1 & $181-199$ & 7 & 13,20 & Tidak pernah \\
\hline 2 & $200-218$ & 15 & 28,30 & Kurang \\
\hline 3 & $219-237$ & 4 & 7,54 & $\begin{array}{c}\text { Kadang - } \\
\text { kadang }\end{array}$ \\
\hline 4 & $238-256$ & 21 & 39,62 & Sering \\
\hline 5 & $257-275$ & 6 & 11,32 & Sangat sering \\
\hline \multicolumn{2}{|c|}{ Jumlah } & 53 & 100 & \\
\hline
\end{tabular}

Berdasarkan tabel tersebut (tabel 2) dapat dikatakan bahwa gambaran variabel motivasi kerja guru tergolong sering karena dari 53 responden terdapat 16 responden atau sebesar $30,19 \%$ dengan variasi jumlah skor dari $105-$ 116.

Tabel 2. Distribusi frekuensi variable motivasi kerja guru

\begin{tabular}{|c|c|c|c|c|}
\hline $\begin{array}{c}\text { No } \\
\text { Kelas }\end{array}$ & Interval & $\begin{array}{c}\text { Frekuensi } \\
\text { Absolut }\end{array}$ & $\begin{array}{c}\text { Frekuensi } \\
\text { Relatif } \\
(\%)\end{array}$ & Kategori \\
\hline 1 & $69-80$ & 6 & 11,32 & $\begin{array}{c}\text { Tidak } \\
\text { pernah }\end{array}$ \\
\hline 2 & $81-92$ & 11 & 20,75 & Kurang \\
\hline 3 & $93-104$ & 15 & 28,30 & $\begin{array}{c}\text { Kadang } \\
\text { kadang }\end{array}$ \\
\hline 4 & $105-116$ & 16 & 30,19 & Sering \\
\hline 5 & $117-124$ & 5 & 9,43 & $\begin{array}{c}\text { Sangat } \\
\text { sering }\end{array}$ \\
\hline
\end{tabular}

Berdasarkan tabel tersebut (tabel 3) dapat dikatakan bahwa gambaran kinerja guru tergolong baik karena dari 53 responden terdapat 19 responden atau sebesar 35,84\% dengan variasi jumlah skor dari 174-188.

Pengujian hipotesis pada penelitian ini menggunakan analisis regresi ganda. Dalam penelitian ini untuk menguji hipotesis digunakan program SPSS versi 19 for Windows. Berikut ini tabel hasil pengujian hipotesis yang dilakukan menggunakan program SPSS versi 19 for Windows. 
Tabel 3. Distribusi Frekuensi Variable Kinerja Guru

\begin{tabular}{|c|c|c|c|c|}
\hline $\begin{array}{c}\text { No } \\
\text { Kelas }\end{array}$ & Interval & $\begin{array}{c}\text { Frekuensi } \\
\text { Absolut }\end{array}$ & $\begin{array}{c}\text { Frekuensi } \\
\text { Relatif } \\
(\%)\end{array}$ & $\begin{array}{c}\text { Katego } \\
\text { ri }\end{array}$ \\
\hline 1 & $\begin{array}{c}129- \\
143\end{array}$ & 10 & 18,86 & $\begin{array}{c}\text { Sangat } \\
\text { Kurang }\end{array}$ \\
\hline 2 & $\begin{array}{c}144- \\
158\end{array}$ & 9 & 16,99 & Kurang \\
\hline 3 & $\begin{array}{c}159- \\
173\end{array}$ & 11 & 20,75 & Cukup \\
\hline 4 & $\begin{array}{c}174- \\
188\end{array}$ & 19 & 35,84 & Baik \\
\hline 5 & $\begin{array}{c}189- \\
204\end{array}$ & 4 & 7,54 & $\begin{array}{c}\text { Sangat } \\
\text { Baik }\end{array}$ \\
\hline \multicolumn{2}{|r|}{ Jumlah } & 53 & 100 & \\
\hline
\end{tabular}

Tabel 4. Pengaruh Kepemimpinan

Transaksional Kepala Sekolah $\left(X_{1}\right)$ Dan Motivasi Kerja Guru $\left(\mathbf{X}_{2}\right)$ Secara BersamaSama Terhadap Kinerja Guru (Y).

\begin{tabular}{|l|r|r|r|r|}
\hline & & $\mathrm{R}$ & Adjusted R \\
Model & $\mathrm{R}$ & $\begin{array}{c}\text { Std. Error } \\
\text { of the } \\
\text { Square } \\
\text { Estimate }\end{array}$ \\
\hline 1 & $\begin{array}{r}\text { Square } \\
\mathrm{a}\end{array}$ &, 430 &, 719 & 9,342 \\
\hline
\end{tabular}

a. Predictors: (Constant), Motivasi Kerja Guru (X2), Kepemimpinan Transaksional Kepala Sekolah (X1)

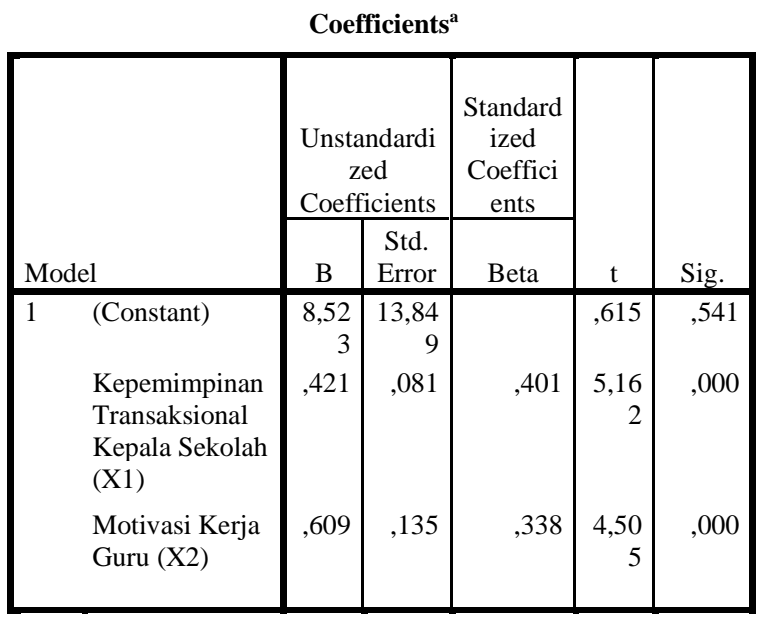

a. Dependent Variable: Kinerja Guru (Y)
Berdasarkan tabel tersebut, diperoleh pengaruh antara variable sebagai berikut:

a. Pengaruh

Kepemimpinan

Transaksional Kepala Sekolah $\left(\mathrm{X}_{1}\right)$ terhadap Kinerja Guru (Y) Beta $\left(b_{1}\right)$ sebesar 0,401. Artinya pengaruh kepemimpinan transaksional kepala sekolah terhadap motivasi kerja guru.

b. Pengaruh Motivasi Kerja Guru $\left(\mathrm{X}_{2}\right)$ terhadap Kinerja Guru (Y) Beta $\left(b_{2}\right)$ sebesar 0,338. Artinya pengaruh Motivasi Kerja terhadap Kinerja Guru.

\section{c. Pengaruh Kepemimpinan} Transaksional Kepala Sekolah $\left(\mathrm{X}_{1}\right)$ dan Motivasi Kerja Guru $\left(\mathrm{X}_{2}\right)$ dapat dilihat dari $\mathrm{R}^{2}$ ( $R$ Square) sebasar 0,439. Hal ini menunjukkan bahwa persentase pengaruh variabel independen (kepemimpinan transaksional kepala sekolah dan Motivasi Kerja Guru) terhadap variabel dependen (Kinerja Guru) sebesar 43,90 \%. Dengan demikian, dapat disimpulkan bahwa terdapat pengaruh antara kepemimpinan transaksional kepala sekolah dan Motivasi Kerja Guru terhadap Kinerja Guru sebesar 43,90\%.

Peneliti menggunakan Uji $F$ untuk mengetahui pengaruh dari variabel bebas terhadap variabel terikat secara bersama-sama. Uji ini digunakan untuk mengetahui apakah variabel independen secara bersama-sama berpengaruh signifikan terhadap variabel dependen. Dengan kata lain untuk mengetahui apakah model regresi dapat digunakan untuk memprediksi variabel dependen atau tidak. Signilfikan berarti pengaruh yang tetjadi dapat berlaku untuk populasi atau dapat digeneralisasikan.

Hasil uji $F$ dapat dilihat pada output ANOVA dari hasil analisis regresi linear berganda di atas sebagai berikut: 
ANOVA ${ }^{\mathbf{b}}$

\begin{tabular}{|l|r|r|r|r|c|}
\hline Model & $\begin{array}{c}\text { Sum of } \\
\text { Squares }\end{array}$ & Df & $\begin{array}{c}\text { Mean } \\
\text { Square }\end{array}$ & F & Sig. \\
\hline 1 Regressio & 806,926 & 2 & 590,46 & 17,644 &, $000^{\mathrm{a}}$ \\
$\mathrm{n}$ & & & 3 & & \\
Residual & 463,603 & 50 & 37,272 & & \\
Total & 1270,52 & 52 & & & \\
& 9 & & & & \\
\hline
\end{tabular}

a. Predictors: (Constant), Motivasi Kerja Guru (X2), Kepemimpinan Transaksional Kepala Sekolah (X1) b. Dependent Variable: Kinerja Guru (Y)

\section{Tabel 5. Tabel hasil Uji F}

1) Hipotesis

Ho Kepemimpinan Transaksional Kepala

: $\quad$ Sekolah $\left(\mathrm{X}_{1}\right)$ dan Motivasi Kerja Guru $\left(\mathrm{X}_{2}\right)$ tidak berpengaruh secara signifikan terhadap Kinerja Guru (Y)

Ha Kepemimpinan Transaksional Kepala

: $\quad$ Sekolah $\left(\mathrm{X}_{1}\right)$ dan Motivasi Kerja Guru $\left(\mathrm{X}_{2}\right)$ berpengaruh secara signifikan terhadap Kinerja Guru (Y)

2) Penentuan $F$ hitung berdasarkan tabel di atas sebesar 17,644.

3) Penentuan $F$ table dengan menggunakan tingkat keyakinan 95\% $(\alpha=5 \%$ atau 0,05$)$ df (jumlah variable-1) atau 3-1 $=2$. Kemudian df $2(n-k-1)$ atau 53-2-1 $=50$. Adapun hasil yang diperoleh untuk $\mathrm{F}$ table sebesar 3,18.

4) Kriteria pengujian hipotesis adalah:

a) Ho diterima apabila $F$ hitung $\leq F$ table

b) Ho ditolak apabila $\mathrm{F}$ hitung $\geq \mathrm{F}$ table

Berdasarkan hipotesis tersebut, maka Ho ditolak, $\mathrm{H}_{\mathrm{a}}$ diterima, karena hasil $\mathrm{F}_{\text {hitung }}>\mathrm{F}_{\text {table }}$ $(17,644>3,18)$. Dengan demikian, terdapat pengaruh kepemimpinan transaksional kepala sekolah $\left(\mathrm{X}_{1}\right)$ dan motivasi kerja guru $\left(\mathrm{X}_{2}\right)$ terhadap kinerja guru (Y). Artinya kepemimpinan transaksional kepala sekolah dan motivasi kerja guru secara bersama-sama berpengaruh terhadap kinerja guru. Jadi, dalam penelitian ini dapat disimpulkan bahwa kepemimpinan transaksional kepala sekolah dan motivasi kerja guru secara bersama-sama berpengaruh terhadap kinerja guru di SMP Negeri Se Kecamatan Rasau Jaya.

\section{Pembahasan}

Hal terpenting yang harus ada dalam seorang guru adalah motivasi karena akan berpengaruh terhadap kinerja. Kinerja tersebut pada akhirnya akan berpengaruh terhadap pencapaian tujuan sekolah dan pencapaian prestasi guru tersebut..

\section{Pengaruh Kepemimpinan Transaksional Kepala Sekolah Terhadap Kinerja Guru}

Berdasarkan hasil penelitian ini diketahui bahwa gambaran kepemimpinan transaksional kepala sekolah di di SMP Negeri Se Kecamatan Rasau Jaya tergolong tinggi atau baik, hal ini dapat diketahui melalui hasil penghitungan dengan jumlah dan persentase responden tertinggi dari total 53 responden yaitu 21 responden atau sebesar 39,62\% dengan variasi jumlah skor 238-256. Sehingga dapat disimpulkan secara menyeluruh bahwa kepemimpinan Transaksional kepala sekolah di SMP Negeri Se Kecamatan Rasau Jaya sudah baik.

Penelitian ini memfokuskan tiga dimensi kepemimpinan Transaksional yang diteliti tingkat pengaruhnya terhadap kinerja guru, di antaranya (1) Pemberian penghargaan kepada bawahan, (2) Pengawasan kepada bawahan secara direktif atau aktif, (3) Pengawasan kepada bawahan secara pasif. Melalui ketiga dimensi tersebut kemudian dijabarkan menjadi subindicator, indicator, hingga menjadi item pertanyaan penelitian. Hasil penelitian ini juga menunjukkan bahwa terdapat pengaruh kepemimpinan Transaksional kepala sekolah terhadap kinerja guru sebesar 50,10\%. Hal ini berarti bahwa semakin baik kepemimpinan Transaksional kepala sekolah maka akan sangat berpengaruh terhadap kinerja guru tersebut. Persentase pengaruh ini terbilang cukup besar dalam mempengaruhi besar kecilnya kinerja guru SMP di Kecamatan Rasau Jaya.

Temuan ini sejalan dengan pendapat Henry Simanora (1997, p.500) yang berpendapat bahwa terdapat berbagai faktor yang mempengaruhi kinerja di antaranya faktor individual yang terdiri dari (kemampuan dan keahlian, latar belakang an demografi), faktor psikologis meliputi (persepsi, attitude, personality, pembelajaran dan motivasi, dan faktor organisasi yang meliputi di antaranya 
(kepemimpinan, penghargaan, struktur, job design dan sumber daya). Hal ini sejalan dengan pendapat Piddarta (2004) dalam Manik dan Bustomi (2011, p.100) ada beberapa faktor yang mempengaruhi kinerja guru yaitu kepempinan kepala sekolah, fasilitas kerja, harapan - harapan dan kepercayaan personalia kepala sekolah.

Adanya pengaruh kepemimpinan Transaksional kepala sekolah terhadap kinerja guru dalam penelitian ini juga dikemukakan dalam teori bahwa kepemimpinan transaksional memiliki hubungan pemimpinpengikut berdasarkan pada suatu rangkaian pertukaran atau persetujuan antara pemimpin dan pengikut (Howell dan Avolio, 1993). Dan hal ini dikemukakan pula oleh Robbins and Judge (2013, p.472) yang mengemukakan bahwa kepemimpinan transaksional adalah pemimpin yang memandu atau memotivasi para pengikut mereka menuju ke sasaran yang ditetapkan dengan memperjelas persyaratan peran dan tugas.

Temuan ini sejalan dengan penelitian yang dilakukan oleh Bass dalam Shadre dan Ayo, (2009, p.10) menyimpulkan bahwa kinerja dipengaruhi oleh motivasi kerja karyawan baik intrinsik maupun ekstrinsik dan efektifitas kepemimpinan semakin efektifitas kepemimpinan semakin tinggi tingkat kinerja individu karyawan. Adapun faktor - faktor yang mempengaruhi kinerja karyawan menurut Wirawan (2009, p.6) kinerja pegawai merupakan hasil sinergi dari jumlah faktor. Faktor - faktor tersebut adalah faktor lingkungan internal organisasi yang meliputi (visi, misi dan tujuan organisasi, kebijakan organisasi,bahan mentah, teknologi, strategi organisasi,sistem manajemen, kompensasi, kepemimpinan, modal, budaya organisasi, iklim organisasi dan teman sekerja), kemudian adanya faktor lingkungan eksternal yaitu (kehidupan ekonomi, kehidupan politik, kehidupan sosial, budaya dn agama masyarakat dan kompetitor), kemudian adanya faktor internal karyawan atau pegawai yaitu (bakat, kreativitas dan pengalaman kerja).

Beberapa hasil penelitian yang relevan dan sejalan dengan hasil penelitian ini salah satunya penelitian yang dilakukan oleh Fadude dkk tahun 2019, yang berjudul, "Pengaruh Kepemimpinan, Budaya Organisasi, dan Kompetensi Terhadap Kinerja Karyawan Pt. Bank Syariah Mandiri Cabang Bitung". Penelitian ini dimuat di dalam Jurnal EMBA. Vol 7 No. 1 yang menunjukkan hasil penelitian bahwa secara parsil kepemimpinan signifikan pengaruhnya Semakin baik kepemimpinan yang diterapkan maka semakin baik pula kinerja karyawannya. Demikian sebaliknya Semakin buruk kepemimpinan yang diterapkan maka semakin buruk pula kinerja karyawannya. Kemudian penelitian yang di lakukan oleh Candra, dkk (2019) dalam jurnal Pendidikan IPS Vol 6 No 1 yang berjudul, "Pengaruh gaya kepemimpinan, budaya sekolah dan motivasi terhadap kinerja guru SMP swasta" kesimpulan dalam penelitian ini bahwa gaya kepemimpinan $\left(\mathrm{X}_{1}\right)$, budaya sekolah $\left(\mathrm{X}_{2}\right)$, dan motivasi $\left(\mathrm{X}_{3}\right)$ memiliki pengaruh yang positif terhadap kinerja guru (Y) pada SMP Swasta Sultan Agung Pematangsiantar. Hal ini dapat dilihat dari hasil pengujian regresi yang menunjukkan tanda positif pada persamaan sebagai berikut: $\mathrm{Y}=7,480+0,354 \cdot \mathrm{X} 1+0,269 \cdot \mathrm{X} 2+0,241 \cdot \mathrm{X} 3$. Berdasarkan hasil uji korelasi, menunjukkan bahwa gaya kepemimpinan, budaya sekolah, dan motivasi masing - masing memiliki korelasi yang sangat kuat dan signifikan terhadap kinerja guru SMP Swasta Sultan Agung Pematangsiantar. Secara parsial (Uji-t), gaya kepemimpinan, budaya sekolah, dan motivasi berpengaruh signifikan terhadap kinerja guru SMP Swasta Sultan Agung Pematangsiantar. Berdasarkan pengaruh secara parsial yang terjadi antara variabel bebas (gaya kepemimpinan, budaya sekolah, dan motivasi) terhadap kinerja guru, dapat disimpulkan bahwa pengaruh yang paling dominan diantara ketiganya adalah variabel gaya kepemimpinan. Hasil presentase penilaian pengaruh kinerja guru SMP Swasta Sultan Agung Pematangsiantar yaitu sebesar 83,2\% (uji determinasi, $\mathrm{R} 2=0,823$ ) dengan gaya kepemimpinan, budaya sekolah, dan motivasi, dan sisanya $(16,8 \%)$ dapat dijelaskan oleh faktor lain yang tidak dibahas dalam penelitian ini, seperti komitmen organisasi, kompetensi, 
kepuasan kerja, iklim organisasi, dan faktor lainnya.

Kedua hasil penelitian yang dinilai relevan ini memang tidak menujukkan nilai persentase pengaruh yang diberikan kepemimpinan Transaksional terhadap motivasi kerja guru, namun menemukan adanya pengaruh langsung dan signifikan. Robbins and Judge (2013, p.417) pemimpin transaksional mengindentifikasi keinginan atau pilihan bawahan dan membantu mereka mencapai kinerja yang menghasilkan reward yang dapat memuaskan bawahan. Hal senada di kemukakan oleh Ene (2020, p.42) "Transactional focus on the role of supervision, organization and group performance and they base leadership on a system of rewards and punishments for meeting particular objectives". Kepemimpinan transaksional merupakan model gaya kepemimpinan dengan cara memusatkan pada pencapaian tujuan atau sasaran, namun tidak berupaya mengembangkan tanggung jawab dan wewenang bawahan demi kemajuan bawahan (Ismail, et al, 2010, p.91).

Memahami pentingnya kepemimpinan Transaksional yang dapat mempengaruhi motivasi kerja guru bawahannya, dalam hal ini adalah guru, maka idealnya seluruh dimensi dari variable kepemimpinan Transaksional kepala sekolah seharusnya tergolong sangat baik sehingga dapat menjadi salah satu instrument penting dalam upaya meningkatkan kinerja guru. Oleh karena itu semakin baik kepemimpinan kepala sekolah dan motivasi kerja maka semakin tinggi pula kinerja guru tersebut.

\section{Pengaruh Motivasi Kerja Terhadap Kinerja Guru}

Motivasi sering dimaknai dengan istilah dorongan, yaitu tenaga yang menggerakkan jiwa dan jasmani untuk berbuat, sehingga motif merupakan "driving force" seseorang untuk bertingkah laku dalam mencapai tujuan yang telah ditetapkan. Setiap orang mempunyai motif diri yang tentu bisa berbeda antara orang yang satu dengan yang lainnya. Menurut Simamora (2018, p.456) motivasi adalah dorongan psikologis yang mengarahkan seseorang menuju sebuah tujuan.

Berdasarkan hasil penelitian ini diketahui bahwa gambaran motivasi kerja terhadap kinerja guru sekolah khusus yang berada di SMP Negri Se Kecamatan Rasau Jaya tergolong baik, hal ini dapat diketahui melalui penghitungan data bahwa terdapat 16 responden dari total 53 responden atau sebesar $30,19 \%$ dari persentase total dengan variasi jumlah skor dari 105-116. Sehingga dapat disimpulkan secara menyeluruh bahwa mtivasi kerja di SMP Negeri Se Kecamatan Rasau Jaya sudah baik.

Berdasarkan hasil penelitian ini juga dapat disimpulkan bahwa terdapat pengaruh Motivasi Kerja Guru $\left(\mathrm{X}_{2}\right)$ terhadap Kinerja Guru (Y) sebesar $0,338=33,80 \%$. Artinya pengaruh motivasi kerja guru terhadap kinerja guru dapat disimpulkan sebesar 33,80\%. Temuan ini sejalan dengan hasil penelitian terdahulu yang dilakukan oleh Riyadi S dan A Mulyapradana, tahun 2017, yang berjudul, "Pengaruh Motivasi Kerja Terhadap Kinerja Guru Radhatul Atfal Di Kota Pekalongan". Berdasarkan Hasil penelitian antara motivasi kerja terhadap kinerja guru menunjukan nilai sebesar 0,565 berarti variabel (X2) Motivasi Kerja Pegawai berkorelasi "Cukup Kuat" terhadap variabel (Y) (Kinerja Mengajar Guru TK).

Penelitian selanjutnya yang dinilai sesuai dengan pembahasan ini adalah penelitian yang dilakukan Sri (2014) tentang "Pengaruh Kepemimpinan Kepala Sekolah, Motivasi Kerja dan Budaya Sekolah Terhadap Kinerja Guru" penelitian ini mengungkap pengaruh motivasi kerja (X2) terhadap kinerja guru (Y). Hasil analisis korelasi parsial $\mathrm{X} 2$ terhadap $\mathrm{Y}$ menunjukkan ada korelasi antara $\mathrm{X} 2$ dan $\mathrm{Y}$, dengan harga koefisien $r$ sebesar 0,235. Hal ini berarti motivasi kerja perlu ditingkatkan agar kinerja guru akan semakin meningkat. Selain itu sumbangan relatif sebesar $30,88 \%$ dan sumbangan efektif sebesar $13,03 \%$. Pengertian sumbangan efektif adalah pengaruh motivasi kerja terhadap kinerja guru memberikan sumbangan sebesar 13,03\% sedangkan sisanya diberikan dua variabel lainnya yaitu kepemimpinan kepala sekolah dan budaya 
sekolah. Hal ini berarti semakin tinggi motivasi kerja maka akan semakin baik kinerja guru.

Penelitian ini tidak meneliti secara khusus hubungan motivasi kerja terhadap kinerja guru, melainkan terhadap produktivitas sekolah yang dilihat dari kinerja mengajar guru. Sebagai mana dijelaskan bahwa motivasi kerja akan mempengaruhi perilaku atau kinerja guru yang selanjutkan akan berpengaruh secara tidak langsung terhadap produktivitas sekolah termasuk akan berpengaruh terhadap mutu sekolah. Hal ini sesuai dengan hasil penelitian Firmawati dkk. (2017)pengaruh Kepemimpinan Kepala Sekolah Dan Motivasi Kerja Terhadap Kinerja Guru. Hasil penelitian menunjukkan bahwa terdapat pengaruh yang signifikan antara kepemimpinan kepala sekolah dan motivasi kerja secara bersamasama terhadap kinerja guru di SMA Negeri 7 Banda Aceh, yaitu sebesar 96,8\%. Kedua variabel yaitu kepemimpinan kepala sekolah dan motivasi kerja berjalan seiring dengan variabel kinerja guru, artinya semakin baik kepemimpinan kepala sekolah dan motivasi kerja, maka semakin tinggi pula kinerja guru tersebut. Motivasi akan muncul pada guru apabila adanya kesesuaian, kepercayaan dan kepuasan yang diberikan oleh kepala sekolah, serta komunikasi yang lancar antara guru dan kepala sekolah, guru dengan guru, kondisi tersebut dapat meningkatkan kinerja.

Hasil penelitian ini sesuai dengan Pendapat Mulyasa (2017, p.120) "Para pegawai (guru) akan bekerja dengan sungguhsungguh apabila memiliki motivasi yang tinggi. Apabila memiliki motivasi yang positif, ia akan memperlihatkan minat, mempunyai perhatian, dan ingin ikut serta dalam suatu tugas atau kegiatan". Sesuai dengan pendapat tersebut, guru yang masih kurang berhasil dalam mengajar dikarenakan mereka kurang termotivasi untuk mengajar sehingga berdampak terhadap menurunnya produktivitas atau kinerja guru. Untuk itu diperlukan peran kepala sekolah untuk memotivasi para guru untuk meningkatkan kinerjanya. Hasil penelitian lainnya oleh Ardiana (2017) dalam jurnal Akutansi dan Pajak Vol 17 No 2 dengan judul Pengaruh Motivasi Kerja Guru Terhadap
Kinerja Guru Akuntansi SMK di Kota Madiun bahwasanya Motivasi kerja mempunyai pengaruh yang signifikan terhadap kinerja guru akuntansi di SMK Kota Madiun, ini menunjukkan bahwa antara motivasi kerja (X) dengan kinerja guru akuntansi SMK di Kota Madiun (Y) ada pengaruh positif, dan sisanya dipengaruhi oleh variabel-variabel lain. ( Ardiana, 2017, p.21).

Secara umum, Motivasi menjadi satu di antara beberapa faktor yang dapat mempengaruhi kinerja. Uno (2014, p.71) berpendapat bahwa, "Motivasi kerja guru adalah suatu proses yang dilakukan untuk menggerakkan guru agar perilaku mereka dapat di arahkan pada upaya - upaya yang nyata untuk mencapai tujuan yang telah ditetapkan“. Melalui keterangan tersebut dapat diketahui adanya pengaruh motivasi terhadap kinerja bagi guru ataupun unsur lainnya di sekolah. Secara spesifik Menurut Sutrisno (2015, p.116) menjelaskan bahwa adanya faktor-faktor motivasi yang dibagi ke dalam dua kelompok yaitu Faktor eksternal yaitu kondisi lingkungan kerja, kompensasi yang memadai, supervisi yang baik, adanya jaminan pekerjaan, status dan tanggungjawab dan peraturan yang fleksibel. Faktor internal yaitu keinginan untuk hidup, keinginan untuk dapat memiliki, keinginan untuk mendapatkan penghargaan, keinginan untuk memperoleh pengakuan dan keinginan untuk berkuasa.

Hal yang sama menurut Lebih lanjut oleh Tanjung dalam Nurdin (2018, p.77) menyebutkan bahwa beberapa faktor yang dapat mempegaruhi kinerja yaitu kepemimpinan mencakup gaya kepemimpinan dan supervisi. Dalam mencapai tujuan pemimpin dapat menguasai dan mempengaruhi serta memotivasi orang lain. Oleh karena itu, kemampuan memimpin dalam memotivasi bawahan tergantung kepada jiwa kepemimpinanya. Faktor Komunikasi. Mencakup hubungan antara manusia, baik hubungan atasan-bawahan, hubungan sesama atasan dan hubungan sesame bawahan. Komunikasi yang lancar adalah komunikasi terbuka. Faktor Kompensasi. Mencakup: upah, gaji, imbalan/balas jasa, kebijakan manajemen dan aturan administrasi penggajian. 
Kompensasi yang memadai merupakan alat motivasi yang paling ampuh bagi perusahaan untuk memberikan dorongan kepada para karyawan untuk bekerja secara baik. Faktor Prestasi. Mencakup prestasi dan kondisi serta lingkungan kerja yang mendorong prestasi kerja tersebut. Membahas mengenai motivasi kerja, tidak dapat terlepas dari pembahasan mengenai prestasi kerja, karena motivasi kerja merupakan bagian yang terpenting dari tingkah laku kerja tersebut. Sehingga pendapat ini sejalan dengan hasil penelitian bahwa terdapat pengaruh motivasi kerja terhadap kinerja guru.

Menurut Taruh, (2020, p.86), motivasi merupakan kondisi yag menggerakkan diri pegawai untuk mencapai tujuan kerja. Dalam penelitian ini, peneliti merumuskan variable penelitian motivasi kerja berdasarkan pembagian dimensi berdasarkan pendapat menurut Uno (2014, p.73), motivasi kerja guru terdiri dari dua dimensi yaitu motivasi internal dan eksternal. Dimensi internal terdiri dari: tanggung jawab guru dalam melaksanakan tugas, melaksanakan tugas dengan target yang jelas, memiliki tujuan yang jelas dan menantang, ada umpan balik atas hasil pekerjaannya, memiliki perasaan senang dalam bekerja, selalu berusaha untuk mengungguli orang lain serta diutamakan prestasi dari apa yang dikerjakannya. Sementara dimensi eksternal terdiri dari: selalu berusaha untuk memenuhi kebutuhan hidup dan kebutuhan kerjanya, senang memperoleh pujian dari apa yang dikerjakanya, bekerja dengan harapan ingin memperoleh insentif dan bekerja dengan harapan ingin memperoleh perhatian dari teman dan atasan.

Secara ekologi, peneliti berdasarkan uraian tersebut maka dapat disintesiskan bahwa Motivasi kerja guru dalam penelitian ini adalah dorongan yang mempengaruhi bekerja seseorang baik dari dalam atau dari luar diri yang terwujud dalam aktifitas pada saat menjalankan tugas dan tanggungjawabnya serta penampilan hasil kerja baik secara kuantitas maupun kualitas. Secara sosial, peneliti ingin mengetahui pola kinerja guru dengan sesama guru, hingga guru dengan peserta didik. Secara lingkungan, peneliti ingin mengetahui unsur keterlibatan kepemimpinan kepala sekolah dalam mewujudkan kinerja guru yang baik, hingga komunikasi sosial yang terjadi di sekolah tersebut. Sementara pada dimensi transaksional, peneliti memasukkan pertanyaan seputar asumsi dan pola fikir guru dalam memaknai kinerja dan motivasi di tempat ia mengajar.

Berdasarkan penelitian ini, motivasi kerja memiliki pengaruh yang signifikan terhadap kinerja guru. Hal tersebut berdasarkan pendapat Menurut Schunk, et al (2010) dalam Usman (2014, p.275) "motivasi is the process whereby goal-directed activity is instigated and sustained". Motivasi adalah proses melalui kegiatan pencapaian tujuan yang telah mendorong dan berkelanjutan. Kepala sekolah dapat memotivasi guru dengan cara yang berbeda-beda sesuai dengan pola-pola masingmasing yang paling menonjol. Pengetahuan tentang pola motivasi membantu pemimpin memahami sikap kerja bahawannya. Guru perlu dimotivasi karena ada guru yang baru mau bekerja setelah dimotivasi atasannya.

Menurut Robbins and Judge (2013, p.417) pemimpin transaksional mengindentifikasi keinginan atau pilihan bawahan dan membantu mereka mencapai kinerja yang menghasilkan reward yang dapat memuaskan bawahan. Hal senada di kemukakan oleh Ene (2020, p.42) "Transactional focus on the role of supervision, organization and group performance and they base leadership on a system of rewards and punishments for meeting particular objectives". Hal ini memberikan beberapa kesimpulan mengenai pentingnya motivasi yang diberikan oleh pemimpin, salah satunya adalah termasuk kepercayaan, menghormati, saling mengerti kewajiban dan perhatian untuk kesejahteraan lainnya, memilki pengaruh yang kuat terhadap pendidik dan peserta didik, hubungan antara peserta didik serta prestasi akademis dan kemajuan sekolah secara keseluruhan.

\section{Pengaruh Kepemimpinan Transaksional Kepala Sekolah dan Motivasi Kerja Guru Terhadap Kinerja Guru}

Berdasarkan hasil penelitian yang ditampilkan pada tabel 4.6 pada bagian sebelumnya, maka dapat dikatakan bahwa gambaran motivasi kerja guru di Sekolah 
Menengah Pertama Negeri Kecamatan Rasau Jaya Kabupaten Kubu Raya tergolong sering, dengan jumlah dan persentase responden tertinggi dari total 53 responden yaitu 19 responden atau sebesar $35,84 \%$ dengan variasi jumlah skor 174-188.

Berdasarkan hasil penelitian ini juga dapat disimpulkan bahwa terdapat pengaruh variable kepemimpinan transaksional kepala sekolah $\left(\mathrm{X}_{1}\right)$ dan motivasi kerja guru $\left(\mathrm{X}_{2}\right)$ terhadap motivasi kerja guru (Y) sebesar 43,90\%. Hal ini menunjukkan bahwa persentase pengaruh variabel independen $\left(\mathrm{X}_{1}\right.$ dan $\left.\mathrm{X}_{2}\right)$ terhadap variabel dependen (Y) sebesar 43,90\%.

Hal ini relevan dengan pendapat Robbins and Judge, (2013, p.472) yang mendefinisikan bahwa kepemimpinan transaksional adalah pemimpin yang memandu atau memotivasi para pengikut mereka menuju ke sasaran yang ditetapkan dengan memperjelas persyaratan peran dan tugas. Motivasi menjadi satu di antara beberapa faktor yang dapat mempengaruhi kinerja. Uno (2014, p.71) berpendapat bahwa, "Motivasi kerja guru adalah suatu proses yang dilakukan untuk menggerakkan guru agar perilaku mereka dapat di arahkan pada upaya - upaya yang nyata untuk mencapai tujuan yang telah ditetapkan“. Semakin tinggi motivasi kerja seseorang, semakin besar ekspektasi yang mereka miliki, maka semakin tinggi pula pengorbanan yang mereka berikan. Manusia pada hakikatnya membutuhkan dorongan atau motivasi untuk melakukan kinerja yang lebih baik.

Adanya pengaruh antara ketiga variable tersebut didukung oleh penelitian yang dilakukan oleh Marliana Y, tahun 2017 berjudul "Pengaruh Kepemimpinan Kepala Sekolah Dan Motivasi Guru Terhadap Kinerja Guru (Studi Kasus di SMP Tulus Kartika Kota Bandung)". Hasil penelitian menunjukkan Kepemimpinan kepala sekolah dan Motivasi guru berpengaruh terhadap kinerja guru secara simultan dengan nilai rendah yaitu dengan koefisien regresi sebesar 0,521 dan koefisien determinan sebesar 0,272 atau $27,2 \%$ dan sisanya dipengaruhi oleh faktor lain sebesar 0761 atau $72,8 \%$.
Hal ini menunjukkan bahwa kinerja guru dipengaruhi dengan korelasi rendah oleh Kepemimpinan kepala sekolah dan Motivasi guru, yaitu apabila Kepemimpinan kepala sekolah dan Motivasi guru secara bersamasama mengalami kenaikan sebesar satu-satuan, maka kinerja guru akan meningkat sebesar 0,272 satuan

Indikator kinerja guru dalam penelitian ini sesuai dengan Permendiknas no 16 tahun 2007 tentang standar kualifikasi akademik dan kompetensi guru di antaranya adalah : pedagogik, keperibadian, sosil, dan profesional. Hal ini di dukung dengan pendapat Dessler (1997, p.515) tentang indikator kinerja guru yaitu: (1) Kualitas, yang terdiri dari: ketelitian, dan kelengkapan hasil kerja; (2) Kuantitas yang terdiri dari volume keluaran dan kontribusi; (3) supervisi yang diperlukan terdiri dari membutuhkan saran, arahan atau perbaikan; (4) kehadiran yang terdiri dari regularitas, dapat dipercaya/diandalkan, dari ketepatan waktu; (5) konservasi yang terdiri dari pencegahan pemborosan, kerusakan, dan pemeliharaan.

Hal ini didukung dengan adanya observasi yang dilakukan di lapangan bahwasannya aspek - aspek yang diamati guru telah melaksanakan tugasnya dengan adanya perangkat kerja berupa RPP, terlaksananya supervisi,adanya absensi kehadiran guru hal ini dilakukan karna untuk melihat sejauh mana kinerja guru.

Keterangan lain menjelaskan dalam UU No.14 Tahun 2005 Bab IV pasal 20 (a) tentang guru dan dosen menyatakan bahwa standar prestasi kerja guru atau dosen menyatakan bahwa standar prestasi kerja guru dalam melaksanakan tugas keprofesionalannya, guru berkewajiban merencanakan pembelajaran, melaksanakan proses pembelajaran yang bermutu serta menilai dan mengevaluasi hasil pembelajaran.

Temuan ini sejalan dengan pendapat Robbins \& Judge, (2011, p.281) kinerja seseorang sangat dipengaruhi oleh faktor kemampuan (ability), motivasi (motivation), dan kesempatan (opportunity), yaitu performance artinya kinerja merupakan fungsi dari kemampuan, motivasi dan kesempatan 
Hal ini juga didukung oleh pendapat Henry Simamora dalam Mangkunegara (2019, p.14), menjelaskan terdapat tiga faktor yang berpengaruh terhadap kinerja, yaitu: (1) faktor individu (kemampuan, ketrampilan, latar belakang keluarga, tingkat sosial dan demografi seseorang); (2) faktor psikologis (persepsi, peran, sikap, kepribadian, motivasi dan pembelajaran); dan (3) faktor organisasi (sumber daya, desain pekerjaan, kepemimpinan, sistem penghargaan atau reward system dan struktur)".

Pendapat yang relevan dengan pendapat Muda dkk (2014) dalam International Journal of Business and Social Science. Vol 5 No. 2 yang mengatakan bahwa, "This performance relates to the firm or individual level which sees the human resource becoming the most determining factor to achieve the organizations' objectives". Menurutnya kinerja seseorang akan sangat berkaitan dengan tingkat pencapaian tujuan suatu perusahaan atau lembaga.

Penelitian lainnya yang relevan dilakukan Firmawati tahun 2017 berjudul tentang "Pengaruh Kepemimpinan Kepala Sekolah Dan Motivasi Kerja Terhadap Kinerja Guru". Hasil penelitian menunjukkan bahwa terdapat pengaruh yang signifikan antara kepemimpinan kepala sekolah dan motivasi kerja secara bersama-sama terhadap kinerja guru di SMA Negeri 7 Banda Aceh, yaitu sebesar 96,8\%. Kedua variabel yaitu kepemimpinan kepala sekolah dan motivasi kerja berjalan seiring dengan variabel kinerja guru, artinya semakin baik kepemimpinan kepala sekolah dan motivasi kerja, maka semakin tinggi pula kinerja guru tersebut. Motivasi akan muncul pada guru apabila adanya kesesuaian, kepercayaan dan kepuasan yang diberikan oleh kepala sekolah, serta komunikasi yang lancar antara guru dan kepala sekolah, guru dengan guru, kondisi tersebut dapat meningkatkan kinerja.

Kinerja guru sangat penting untuk diperhatikan.dan sangat dibutuhkan bagi setiap individu, salah satunya para guru untuk kebaikan pribadi dan lembaga sekolahnya. Hal ini berdasarkan pendapat Muchal (2014) dalam Omari dan Okasheh (2017, p.154), bahwa pentingnya kinerja guru akan sangat menentukan kesuksesan suatu usaha, dalam hal ini kesuksesan pencapaian tujuan pendidikan.

\section{SIMPULAN DAN SARAN Simpulan}

Simpulan dalam penelitian ini adalah: (1) gambaran kepemimpinan Transaksional Kepala Sekolah $\left(\mathrm{X}_{1}\right)$ mempunyai pengaruh yang positif dan signifikan terhadap Kinerja Guru (Y) di SMP Negeri Se-Kecamatan Rasau Jaya terlihat dengan adanya pemberian penghargaan kepada bawahan, adanya pengawasan kepada bawahan secara direktif atau aktif serta adanya pengawasan secara pasif. (2) Motivasi Kerja Guru $\left(\mathrm{X}_{2}\right)$ mempunyai pengaruh yang positif dan signifikan hal ini memberikan beberapa kesimpulan mengenai pentingnya motivasi yang diberikan oleh pemimpin, salah satunya adalah termasuk kepercayaan, menghormati, saling mengerti kewajiban dan perhatian untuk kesejahteraan lainnya, memilki pengaruh yang kuat terhadap pendidik dan peserta didik, hubungan antara peserta didik serta prestasi akademis dan kemajuan sekolah secara keseluruhan sehingga berpengaruh terhadap Kinerja Guru (Y) di SMP Negeri SeKecamatan Rasau Jaya. (3) Kepemimpinan Transaksional Kepala Sekolah $\left(\mathrm{X}_{1}\right)$ dan Motivasi Kerja Guru $\left(\mathrm{X}_{2}\right)$ secara simultan mempunyai pengaruh yang positif dan signifikan terhadap Kinerja Guru (Y) di SMP Negeri Se-Kecamatan Rasau Jaya. Kedua variabel yaitu kepemimpinan transaksioanal kepala sekolah dan motivasi kerja guru berjalan seiring dengan variabel kinerja guru, artinya semakin baik kepemimpinan kepala sekolah dan motivasi kerja, maka semakin tinggi pula kinerja guru tersebut.

\section{Saran}

Saran dalam penelitian ini adalah: (1)Bagi kepala sekolah menengah pertama hendaknya: Mempertahankan program-program bersifat reward dan punishment yang sudah memberikan pengaruh positif terhadap motivasi kerja guru dan mempraktikkan tipetipe kepemimpinan secara kolaboratif sesuai dengan keadaan sekolah masing-masing sebagai upaya dalam mendukung kinerja guru yang lebih baik. (2) Bagi guru selalu 
meningkatkan motivasi kerja dengan cara kreativitas dan inovasi dalam melaksanakan tugas. (3) Bagi Dinas Pendidikan dan Kebudayaan Kabupaten Kubu Raya hendaknya meningkatkan program-program yang bervariatif bersifat pemberian penghargaan untuk meningkatkan motivasi guru(4)bagi peneliti selanjutnya, yang ingin melaksanakan penelitian pada objek sejenis, disarankan meneliti dari sudut pandang atau variable lainnya. Ataupun melakukan penelitian dengan pendekatan kualitatif sehingga dapat melihat lebih dalam lagi.

\section{DAFTAR RUJUKAN}

Algahtany, M. A. M., \& Bardai B. (2019). Quality Attention/ Contingent Reward and Leadership Styles (Transformational / Transactional). SSRG International Journal of Economics Management Studies (SSRGIJEMS) 6 (2), 57-81

Ardiana E T. (2017). Pengaruh Motivasi Kerja Guru Terhadap Kinerja Guru Akutansi SMK di Kota Madiun. Jurnal Akutansi dan Pajak, 17(02), 14-23.

Candra V. P. S., \& A Sudirman. (2019). Pengaruh Gaya Kepemimpian, Budaya Sekolah dan Motivasi Terhadap Kinerja Guru SMP Swasta. Jurnal Pendidikan IPS, 6(1), 49-60.

Depdiknas. (2008). Permendiknas No. 16 Tahun 2007 tentang Standar Kualifikasi dan Kompetensi Guru. Jakarta: Depdiknas.

Dessler, G. (1997). Manajemen Personalia, Edisi 3. Jakarta: Erlangga.

Ene Chinwe. (2020). Transactional Leadership Style and Employee Intention to Stay in Insurance Companies in Port Harcourt, Rivers State. International Journal of Innovative Social Sciences \& Humanities Research, 8(1):40-47.

Fadude, D.F., Tawas NH., \& Poluan JG. (2019). Pengaruh Kepemimpinan, Budaya Organisai dan Kompetensi Terhadap Kinerj Karyawan PT Bank Syariah Mandiri Cabang Bitung. Jurnal EMBA, 7(1), 31-40.

Firmawati, Yusrizal \& N Usman. (2017). Pengaruh Kepemimpinan Kepala Sekolah Dan Motivasi Kerja Terhadap Kinerja Guru. Jurnal Magister Administrasi Pendidikan, 5 (3), 167-171
Gibson, J.L., Ivancevich J.M., \& Donnelly JH. (1985). Organisasi: Perilaku, Struktur, dan Proses. Jilid 1 Edisi Kelima. Dharma, A. Ed. Jakarta: Penerbit Erlangga

Guterres A. L., \& W. G. Supartha. (2016). Pengaruh Gaya Kepemimpinan dan Motivasi Kerja Terhadap Kinerja Guru. EJurnal Ekonomi dan Bisnis, 5(3), 429-454

Howell, J. M., \& Avolio B J. (1993). Transformational leadership, transactional leadership, locus of control and support for innovation: key predictors of consolidatedbusiness-unit perfomance. Journal of Applied Psychology, 78 (6): 891-902.

Ismail A., Mohamad M.H., Mohamde H.A., Rafiuddin N.M., Zhen K.W.P. (2010). Transformasional and Transactional Leadership Styles as a Predictor of Individual Outcomes. Theoretical and Applied Economics. Vol. 17 No 6 (547), pp $89-104$.

Kemdikbud. (2005). Undang-Undang No. 14 Tahun 2005 tentang Guru dan Dosen. Jakarta: Kemdikbud.

Manik, E., \& K Bustomi. (2011). Pengaruh Kepemimpinan Kepala Sekolah, Budaya Organisasi dan Motivasi Kerja Terhadap Kinerja Guru pada SMP Negeri 3 Rancaekek. Jurnal Ekonomi Bisnis dan Entrepreneurship, 5 (2), 97-107.

Marliana, Y. (2017). Pengaruh Kepemimpinan Kepala Sekolah Dan Motivasi Guru Terhadap Kinerja Guru (Studi Kasus Di SMP Tulus Kartika Kota Bandung). Online. Repository.unpas.ac.id. diakses 13 Januari 2020.

Mangkunegara, P A. (2019). Evaluasi Kinerja SDM. Bandung: PT Refika Aditama.

Muda, I., Rafiki, A., \& Harahap, M.Z. (2014). Factors Influencing Employees' Performance: A Study on the Islamic Banks in Indonesia. International Journal of Business and Social Science. Vol 5 No. 2.

Mulyasa. (2013). Uji Kompetensi dan Penilaian Kinerja Guru. Bandung: Remaja Rosdakarya.

Nurdin, B I. (2018). Faktor - faktor Motivasi Kerja pada Karyawan Lembaga Huda Group di Kecamatan Tamansari Kabupaten 
Bogor. Jurnal Manajemen Pendidikan Islam, 1(1), 70-97.

Omari, K., \& Okasheh, H. (2017). The Influence of Work Environment on Job Performance: A Case Study of Engineering Company in Jordan. International Journal of Applied Engineering Research,12(24), 44-50

Riyadi, S \& A Mulyapradana. (2017). Pengaruh Motivasi Kerja Terhadap Kinerja Guru Radhatul Atfal di Kota Pekalongan. Jurnal Litbang Kota Pekalongan, 13, 106117.

Robbins, S. P., \& Judge, Timothy A. (2011). Organizational Behaviour.

Fourteenth Edition. New Jersey: Pearson Education Inc.

Robbins, S.P., \& Judge, T.A. (2013). Organizational Behavior. Global Edition 15. San Fransisco: Pearson Publishing Ltd.

Simamora H. (2018). Manajemen Sumber Daya Manusia, Edisi III. Yogyakarta: Bagian Penerbitan STIE YKPN.
Sri S. (2014). Pengaruh Kepemimpinan Kepala Sekolah, Motivasi Kerja, dan Budaya Sekolah Terhadap Kinerja Guru. Jurnal Pendidikan Teknologi dan Kejuruan, 13 (2), 200-207.

Sutrisno E. (2015). Manajemen Sumber Daya Manusia. Jakarta: Kecana Prenadamedia Group.

Taruh F. (2020). Motivasi Kerja (Meniti Suara Hati Menolak Perilaku Korupsi). Yogyakarta: Deepublish.

Uno, B. H. (2014). Teori Motivasi \& Pengukurannya (Analisis dibidang Pendidikan). Jakarta. Bumi Aksara.

Usman H. (2014). Manajemen: Teori, Praktek dan Riset Pendidikan. Edisi 4. Jakarta Bumi Aksara.

Wirawan. (2009). Evaluasi Kinerja Sumber Daya Manusia (Teori, Aplikasi, dan Penelitian). Jakarta: Salemba Empat.

Yunus \& T Sukartini. (2013). Manajemen Sumber Daya Manusia. Majalengka: Universitas
Majalengka 